\title{
ERGONOMIC INTERFACE REQUIREMENTS FOR ELECTRONIC TOOLS OF EDUCATIONAL PURPOSE
}

\author{
National Aviation University \\ ${ }^{1}$ E-mail: o.burov@iod.gov.ua \\ ${ }^{2}$ E-mail: staffer@bigmir.net
}

\begin{abstract}
The article reveals the aspect of the "correct" creation of electronic learning tools to enhance learning efficiency and improve the learning process. In particular, the importance and the necessity of ergonomic requirements to the interface design for electronic tools of educational purpose.
\end{abstract}

Keywords: effectiveness of training, efficient interfaces, electronic educational purpose, ergonomic requirements, human-computer interaction, usability.

\section{Introduction}

Number of information sources is growing rapidly, and the speed of processing and assimilation of information in today's students is low. Text books and teaching materials that are published in large numbers today, do not allow huge reserves of productivity of the human brain related to its ability to enhance processing of large volumes of information.

It's necessary to make new approaches and teaching methods. The desired result is achieved if the preparation of textbooks and teaching aids take into account the peculiarities of the human brain and the human psyche that can effectively regulate the conscious and unconscious processes occurring in the human brain. Ergonomics can help you [1].

In education, ergonomics deals with the facilitation and improvement of educational activities. It's a great role of cognitive ergonomics. Cognitive ergonomics is considering the organization of mental work, training and human education. Thus, ergonomics can successfully interact with education, facilitates and improves the learning process. Cognitive ergonomics helps to increase student productivity and saves his time. One of the important tasks of ergonomics is to create an optimal form of educational literature.

Modern electronic learning tools have to improve the quality of students training, to facilitate understanding and memorization of learning material, as well as to help students easily learn a wealth of knowledge with minimal costs of mental labor. Such e-learning tools should contain more visual information.

It is known that a person receives more information with a help of eyes. This is a high speed

(C) Burov Oleksandr, Tsarik Oleksandra, 2012 device of perception. Students read faster electronic learning tools that include charts, graphs and illustrations and their content is better remembered, therefore, productivity of student mental work increases. Modern electronic teaching aids will use visual resources in full, where the principle of clarity is expressed not only in specific visual objects and their images, but also on models [2].

Distribution of text information in electronic form allows you to implement a number of new features that may be deprived of paper issue: crossreferences, contextual search, recourse to dictionaries and reference books and more.

The widespread use of modern technology will improve perception, understanding and mastering of difficult academic material, reduce the training time of student, improve teaching and learning activities in general.

Thus, the use and preparation of teaching material should be implemented on a fundamentally new, higher level. The more senses involved in the perception of information, the more successful is learning process. This issue will help to resolve the new information technology and cognitive ergonomics. It`s a science of training and human education.

Purpose is to formulate and describe the ergonomic interface requirements for electronic tools of educational purpose for their high suitability and efficiency.

\section{General ergonomic requirements for electronic-learning}

General ergonomic requirements set regulation on specific parameters and conditions of application of certain technical and technological solutions, 
particularly in the design of electronic learning tools [3-7].

It should be noted that many of the modern scientific and practical solutions of the issues of human-computer interface can be used for the tasks of education.

Electronic tools for educational purpose should have a high ergonomic design and technological quality and satisfy the following requirements [8]:

- to comply with the normative documents of the state level to the maximum extent, which regulates the content of education (as defining the problems of modernization of education, and currently in force), and programs which are used in the most regions;

- to provide a new quality of education, focus on modern forms of education, high interactivity, increased self-sufficiency training of students;

- to be capable of level differentiation and individualization of learning (this applies both to the level of formation of subject skills, knowledge and intellectual and general skills);

- to consider the age of psychological and pedagogical features of students and the differences in their cultural practices;

- to contain materials that are targeted to work with the information presented in different forms (charts, tables, and compound the original texts of various genres, video sequences, etc.);

- to contain a set of tasks (such as training and diagnostic information), mainly oriented to the nonstandard solutions;

- to provide the organization of training activities, which implies extensive use of forms of self-group and individual research activities, forms and methods of the project organization of the educational process;

- to contain options for planning the educational process which should involve a modular structure that allows to implement an agreed teaching upon division by subjects, grades and topics.

Ergonomic requirements for electronic tools of educational purpose should be built taking into account the age characteristics of trainees, should establish requirements for information display and modes of e-learning tools, to improve the level of motivation to learn.

The requirements of ergonomic character as follows: e-learning tools must meet hygiene requirements and sanitary standards of work with computers.
The basic ergonomic requirement is the requirement to support the one who taught by the organization in electronic learning tools and its components friendly interface necessary tips and guidelines, free sequence and pace of work for the learner.

\section{The development of effective interfaces for electronic-learning tools}

The most effective for a time is technology of the interface ergonomic design - "usability" which includes consideration of various aspects of the ergonomic design of an electronic interface "student-teacher". Usability is a sign of quality, which determines how it's easy to use.

The word "usability" also means a set of methods that serve to improve the interface during the process of its development. Users of interface "student-teacher" are both teacher and student.

Usability has five quantitative components:

1. Educability: how easily users can perform basic tasks, first meeting with the unknown interface.

2. Efficiency: when the users become acquainted with the design, how quickly they can perform the same task.

3. Memorability: when user returns to the interface again after a certain period of time, how easy it will restore his skills with this interface.

4. Errors: how many errors users do, how serious these problems, how easily the user can correct these errors.

5. Satisfaction: how it is pleasant for the user to use this interface.

The development of effective interfaces for e-learning tools is a fundamental principle to improve the interaction of student and technical training means.

Human-computer interaction (HCI) is the science that studies how people use computer systems to solve the problem. HCI provides us with knowledge about the computer and the person to the interaction between them was more effective and more convenient.

HCI includes several different disciplines. This is required so that software developers understand the basics of activity, behavior and mental specific of human in accordance with the designed system.

1. The interaction between the user and the computer. 
Man-machine interface provides communication between the user and the computer - it allows you to achieve our goals, successfully find a solution to the problem. Interaction is an exchange of actions and reactions which are between the computer and the user.

2. Basic principles of interface design:

- natural (intuitive);

- consistency;

- nonredundancy;

- direct access to help;

- flexibility.

3. Placing information on the screen.

The amount of information displayed on the screen, is called the screen density. Studies have shown that the smaller the screen density, the information displayed is the most accessible and understandable to the user and vice versa, if the screen-density is large, it can cause difficulties in the assimilation of information and clear understanding. However, advanced users may prefer to interface with a large screen density. Information on the screen can be grouped and ordered into meaningful parts. This can be achieved with the use of frames (frames) techniques such as color coding framework, a negative image or other methods to attract attention.

4. Isolation of interface elements brightness.

To draw attention to some elements of the interface, you can take advantage of the release of these elements greater brightness compared to other - darker. However, do not overdo it with this method, since a large number of bright elements can cause discomfort to the user. Thus, we can achieve the opposite effect - overloading the interface. Apply this method only when it is necessary. There are several ways to select brightness:

- movement (flashing or changing positions). Very effective method, because the eye has a special detector to move elements;

- brightness. Not so effective method, because people can discover only a few brightness levels;

- color - the use of color can be extremely effective;

- form (symbol, font, shape of the symbol). It is used to distinguish different categories of data;

- the use of different alphabets (fonts) in various forms;

- size (words, characters). It is typically used to increase the selected object by 1.5 times;

- shadows (different texture objects). An efficient method to draw attention to any part of the screen;

- setting (underline, box, inverted image). A very effective method if you do not overdo it.

5. The use of color in the design of ergonomic interface.

Color can improve the user interface, but for many systems, the use of color does not affect the efficiency of the user. The main purpose of color is to create interfaces more interesting for users. However, there are cases where color can help the designer of the user interface. The use of color is the most effective for:

- grouping of information;

- highlight the differences between the information;

- allocation of simple messages (errors, status, etc.)

Color is a powerful visual tool, it is necessary to use very carefully in order to prevent discomfort by the user error of color combinations. Here are some of the principles of color, which should guide the design of ergonomic interface:

- the necessity to limit the number of colors on the screen to 4 and 7 for the sequence of screens, for inactive items where you want to use pale colors;

- if color is used to encode the information, it is necessary to make sure that the user understands the code;

- the necessity to use the colors according to the users ideas;

- to display the status: red $=$ danger $/$ stop, green $=\mathrm{ok} /$ continue working, yellow $=$ caution;

- to highlight the most effective items: white, yellow and red;

- to organize the data you can use to range 7 colors (rainbow);

- to separate the data necessary to select colors from different parts of the spectrum (red / green, blue / yellow, any color / white);

- to group data, association and similarity to use colors that are neighbors in the spectrum (orange / yellow, blue / purple).

It is important to note that about $9 \%$ of people do not distinguish color (usually red - green mix). However, these people can distinguish between black and white shades, so the designers of automated systems have to check, does not affect the perception of users in this category the use of different colors in the interface software.

6. Texts and dialogues. 
Here are some principles that should guide the creation of text dialogues and display on the screen:

- the text in the lower register is read for about $13 \%$ faster than the text that is printed entirely in upper case;

- uppercase letters are the most effective for information that should attract attention. DO NOT USE UPPER CASE, IF YOU DO NOT WANT TO ALLOCATE any information;

- right-justified text is harder to read than the text with evenly distributed misaligned right field;

- the optimal spacing between lines is equal or slightly greater than the height of the characters.

7. Consistency and standardization.

The data on the screen should be positioned so that the user knows where to find and where to expect the output of information.

- Information that should draw an immediate attention should always be displayed in a prominent place to capture the attention of the user (for example, warning messages and error messages).

- Information that is required is not very common (for example means information) should not be displayed, but should be available when it is needed.

- Less urgent information or less important than the required information should not be all the time in front of the user, but should be available when it is needed.

- Reports and references should be grouped together.

In practice, the purpose of creating an ergonomic interface is to display the information as efficiently as possible for the human perception and to create structured display on the screen to draw attention to the most important units of information. But the main purpose is to minimize the overall information on the screen and present only what is necessary for the user.

\section{Conclusions}

In the formation of public information and education space, electronic learning tools are increasingly becoming an integral feature of the educational process.

The use of electronic means of training in education can improve learning, the quality of learning and opens up new possibilities for improving the learning process by changing the level of individualization and differentiation of learning, promotes student-centered learning [3;9-10].
An integral part of a highly suitable and effective electronic means of education are ergonomic requirements for qualifying their design.

The implementation of ergonomic requirements for the creation of electronic interfaces for educational purpose can be achieved by increasing efficiency and improving the learning process.

\section{References}

1. Краснова, Г.А.; Беляев, М.И.; Соловов, А.В. Технология создания электронных обучающих средств. - Москва: МГИУ, 2002. - 304 с.

[Krasnova, G.A.; Belyaev, M.I.; Solovov, A.V. 2002. Technology of creation e-learning tools. Moscow. MGIU. 304 p.] (in Russian).

2. Паронджанов, В. Учебник XX1 века: он может быть эффективнее в 8000 раз [Электронный ресурс]. - Режим доступа: [url=http:// upr.1 september.ru/1999/upr36.htm] http:// upr.1 september.ru/1999/upr36.htm[/url] Загл. с экрана.

[Parondzhanov, B. Textbook HH1 century: it can be more effective than 8000 times (electronic resource). - Mode of access. - [url=http://upr.1 september.ru/1999/upr36.htm]http://upr.1september. ru/1999/upr36.htm[/url] (in Russian).

3. Вострокнутов, И.Е. Теория и технология оценки качества программных средств образовательного назначения. - Москва: Госкоорцентр информационных технологий, 2005. - 300 с.

[Vostroknutov, I.E. 2005. Theory and technology of quality assessment software of educational purposes. Moscow. Goskoorcentr of information Technology. 300 p.] (in Russian).

4. ДСТУ ISO 9241-11:2006 Ергономічні вимоги до роботи 3 відеотерміналами в офісі. Частина 11. Настанови щодо прийнятності у використанні (ISO 9241-11:1998, IDT). - Київ: Держстандарт України, 2007. Чинний.

[DSTU ISO 9241-11:2006 Ergonomic requirements for office work with visual display terminals (VDTs). Part 11. Guidance on usability (ISO 9241-11:1998, IDT). Derzhstandart of Ukraine, 2007. Valid.] (in Ukrainian).

5. ДСТУ EN ISO 13407:2007 Людиноцентричні процеси проектування діалогових систем (EN ISO 13407:1999, IDT). - Київ: Держстандарт України, 2009. Чинний.

[DSTU EN ISO 13407:2007 Human-centred design processes for interactive systems (EN ISO 13407:1999, IDT). Derzhstandart of Ukraine, 2009. Valid.] (in Ukrainian). 
6. ДСТУ EN ISO 10075-2:2004 Ергономічні принципи визначення психічного робочого навантаження. Частина 2. Принципи проектування (EN ISO 10075-2:2000, IDT). - Київ: Держстандарт України, 2006. Чинний.

[DSTU EN ISO 10075-2:2004 Ergonomic principles related to mental workload. Part 2. Design principles (EN ISO 10075-2:2000, IDT). Derzhstandart of Ukraine, 2006. Valid.] (in Ukrainian).

7. ДСТУ ISO 9241-10-2001 Ергономічні вимоги до роботи 3 відеотерміналами в офісі. Частина 10. Принципи діалогу (ISO 9241 10:1996, IDT). - Держстандарт України, 2002. Чинний.

[DSTU ISO 9241-10-2001 Ergonomic requirements for office work with visual display terminals (VDTs). Part 10. Dialogue principles (ISO 9241 10:1996, IDT). Derzhstandart of Ukraine, 2002. Valid.] (in Ukrainian).

8. Положение о конкурсе по разработке наборов цифровых образовательных ресурсов, расширяющих учебники, рекомендованные (допущенные) МОН к использованию в учебном процессе. - Режим доступа: www.ntf.ru.
[Regulations of the competition to develop a set of digital educational resources that enhance textbooks recommended (committed) of MES to the use in the learning process. Available from Internet: $<$ http://www.ntf.ru>] (in Russian).

9. Григорьев, С.Г.; Гриншкун, В.В.; Краснова, Г.А.; Роберт, И.В.; Щенников С.А. Теоретические основы создания образовательных электронных изданий. - Томск: Издво Томского университета, 2002. - 86 с.

[Grigoryev, S.G.; Grinshkun, V.V.; Krasnovf, G.A.; Robert, I.V.; Shchennikov, S.A. 2002. The theoretical basis for the creation of educational electronic media. Tomsk. Publishing house of Tomsk University. 86 p.] (in Russian).

10. Роберт, И.В. Теория и методика информатизации образования (психолого-педагогический и технологический аспекты). - Москва: ИИО PAO, 2008. - $274 \mathrm{c}$.

[Robert, I.V. 2008. Information Theory and Methods of Education (psychological, pedagogical and technological aspects of you). Moscow. ERI RW. 274 p.] (in Russian). 